\title{
Feed intake, nutrient digestibility and ruminal fermentation activities in sheep-fed peanut hulls treated with Trichoderma viride or urea
}

\author{
Fawzy M. Abo-Donia - Safa N. Abdel-Azim • \\ Mona M. Y. Elghandour • Abdelfattah Z. M. Salem • \\ Germán Buendía • N. A. M. Soliman
}

Accepted: 17 September 2013 / Published online: 2 October 2013

(C) Springer Science+Business Media Dordrecht 2013

\begin{abstract}
This study aimed to assess impacts of fungal treatment on the nutritional value of peanut hulls $(\mathrm{PH})$ or urea at the rate of $5 \mathrm{~kg} / 100 \mathrm{~g}$ of $\mathrm{PH}$. Fermented sugar beet pulp inoculated with Trichoderma viride was supplemented to $\mathrm{PH}$ at rates of 5.0, 10.0 and $15.0 \mathrm{~g} / 100 \mathrm{~g}$ air dry of $\mathrm{PH}$ and mixed well before aerobic incubation for 21 days. Organic matter $(\mathrm{OM})$ content of $\mathrm{PH}$ declined with increased levels of fermented sugar beet pulp inoculums, while crude protein (CP), ether extract (EE), and ash increased. Fiber contents were decreased with both treatments of fermented sugar beet pulp and urea. Total $\mathrm{N}$ of $\mathrm{PH}$ increased with urea treatment, which reduced the true protein $\mathrm{N}$ to total protein $\mathrm{N}$ ratio. In sacco degradabilities of dry matter (DM), $\mathrm{OM}$, and $\mathrm{CP}$ with urea treatment increased compared with fungal treatment. The DM intake of peanut hulls treated with fungus $(\mathrm{PHF})$ was higher $(P<0.05)$ than with peanut hulls treated with urea (PHU). Digestibility of OM, CP, neutral detergent fiber, and non-fiber carbohydrate by native breed Ossimi sheep with $\mathrm{PH}$ were higher $(P<0.05)$ than with $\mathrm{PH}$ or urea treated PH. The intakes, losses, and balance of $\mathrm{N}$ increased
\end{abstract}

F. M. Abo-Donia · S. N. Abdel-Azim • N. A. M. Soliman

Animal Production Research Institute,

Ministry of Agriculture, Dokki, Giza, Egypt

M. M. Y. Elghandour · A. Z. M. Salem

Facultad de Medicina Veterinaria y Zootecnia, Universidad

Autónoma del Estado de México, Estado de México, México

G. Buendía

Centro Nacional de Investigación Disciplinaria en Fisiología y

Mejoramiento Animal, INIFAP, Ajuchitlán,

Querétaro 76280, México

\section{A. Z. M. Salem ( $\varangle)$}

Faculty of Agriculture (El-Shatby),

Alexandria University, Alexandria, Egypt

e-mail: asalem70@yahoo.com
$(P<0.01)$ with PHF versus $\mathrm{PH}$ feeding. Feeding PHF increased $(P<0.01)$ ruminal concentrations of $\mathrm{NH}_{3}-\mathrm{N}$, acetic acid, butyric acid, and the acetic to propionic acid ratio. Bacterial and protozoal counts increased $(P<0.05)$ with feeding PHF or PHU versus $\mathrm{PH}$. Overall, this fungal treatment of peanut hulls created a higher nutritive value feed for ruminants.

Keywords Peanut hulls $\cdot$ Fungi $\cdot$ Urea $\cdot$ Digestibility

$\begin{array}{ll}\text { Abbreviations } \\ \text { ADF } & \text { Acid detergent fiber } \\ \text { CP } & \text { Crude protein } \\ \text { DM } & \text { Dry matter } \\ \text { EE } & \text { Ether extract } \\ \text { NDF } & \text { Neutral detergent fiber } \\ \text { OM } & \text { Organic matter } \\ \text { PH } & \text { Peanut hulls } \\ \text { PHF } & \text { Peanut hulls treated with fungus } \\ \text { PHU } & \text { Peanut hulls treated with urea }\end{array}$

\section{Introduction}

Hundreds of thousands of tonnes of peanuts are produced annually in Egypt, and a quarter of this production is hulls (Egyptian Ministry of Agriculture 2006). The majority of peanut hulls are burned or left to decompose in fields. Various methods have been proposed to make use of peanut hulls, including use as supplements in cattle diets (Thomas et al. 1986), but no one method, or even all possible methods, would be able to use all the hulls produced. An interesting and potentially practical method suggested recently (Abdel-Azim et al. 2011) is to use chemical or fungal treatment make peanut hulls more nutritious as a cattle feed. Khaled (2009) attempted 
to increase the digestibility of peanut hulls by treating them with a variety of chemicals, including a number of delignifiers. Best results were obtained with a fungal treatment which increased in vitro DM digestibility of the hulls from 250 to $400 \mathrm{~g} / \mathrm{kg}$. Although this increase in digestibility is not to a high level, Rane et al. (2004) reported that other desirable changes may occur with fungal treatment, such lowering the lignin value. Sarnklong et al. (2010) stated that use of fungi treatment is a practical and environmentally friendly way to enhance the nutritive value of rice straw, and can be cost effective.

Some studies have reported the chemical analysis of raw peanut hulls or described the chemical composition of specific components of the hull (Frank Dean 2002; Khaled 2009), but there are no publications which detail the compositional changes of peanut hulls as a result of chemical or fungal treatments.

Our objectives were to evaluate the effects fungal or urea treatment on upgrading the nutritive value of peanut hulls of chemical composition, in vitro digestibility, in sacco degradability and in vivo digestibility, and ruminal fermentation activities in sheep.

\section{Materials and methods}

The digestibility study was completed at the Seds Experimental Station, Bani Suwayf (governorate), in northern Upper Egypt. In situ and in vitro gas production studies were completed at the Research Unit of Animal Nutrition at Regional Research Station in Ismailia (Egypt) at the Microbiological Laboratory of the Research Department of By-Product Utilization. Stations belong to the Animal Production Research Institute in Giza (Egypt).

Treatments of peanut hulls with fungi and urea

\section{Treatment with Trichoderma viride}

T. viride F.516 was obtained from the Microbial Chemistry Department, National Research Center, Dokki in Giza. A facultative strain was chosen according to suggestions of Raimbault (1998). The pure culture obtained was maintained on potato dextrose agar. Sugar beet pulp is a by-product of sugar beet processing was obtained from the Sugar FactoryEl-Fayoum, Egypt, for use as the substrate for fungal growth.

The fungal inoculum was prepared in $250 \mathrm{ml}$ conical flasks containing $50 \mathrm{mg} / 1$ medium, $5.0 \mathrm{ml}$ peptone, $3.0 \mathrm{ml}$ yeast extract, $3.0 \mathrm{ml}$ malt extract, and $10.0 \mathrm{ml}$ sucrose. Flasks were sterilized by autoclaving at $121{ }^{\circ} \mathrm{C}$ for $15 \mathrm{~min}$. Cooled sterilized flasks were inoculated by a loop of 3-day-old fungal cultures. Inoculated flasks were incubated in a rotary shaker at $150 \mathrm{rpm}$ at $30^{\circ} \mathrm{C}$ for $48 \mathrm{~h}$. The fungal mycelia were used to inoculum the experimental flasks at $10 \mathrm{ml} / 100 \mathrm{~g}(v / w)$.
Five hundred $\mathrm{ml}$ capacity conical flasks containing $25 \mathrm{~g}$ sugar beet pulp moistener at solid: liquid ratio 1:2 with salt medium of $\mathrm{g} / 1.5 \mathrm{~g}$ urea, $75 \mathrm{~g}$ ammonium sulfate, $5 \mathrm{~g}$ potassium dihydrogen phosphate, $0.125 \mathrm{~g}$ magnesium sulfate in $0.05 \mathrm{ml}$ citrate buffer ( $\mathrm{pH}$ 5.2). Flasks were autoclaved at $121^{\circ} \mathrm{C}$ for $30 \mathrm{~min}$. Cooled sterilized flasks were inoculated with this inoculum and then incubated at $30 \pm 2{ }^{\circ} \mathrm{C}$ for $72 \mathrm{~h}$.

Treatments were scaled up to 201 capacity flasks, each containing $400 \mathrm{~g}$ of sugar beet pulp moistened by medium containing $5 \mathrm{ml}$ juice of Savor Cantaloupe (Cucumis melo L.) which contains a high proportion of soluble carbohydrates, which was mixed with $100 \mathrm{ml}$ basal liquid medium containing $0.4 \mathrm{~g}$ urea, $0.2 \mathrm{~g} \mathrm{KH}_{2} \mathrm{PO}_{4}$, and $0.03 \mathrm{~g} \mathrm{MgSO}_{4}: 7 \mathrm{H}_{2} \mathrm{O}$ to achieve a solid: liquid ratio of 1:2 $(\mathrm{v} / \mathrm{w})$. Moistened sugar beet pulp was sterilized in heating bags in an autoclave at $121^{\circ} \mathrm{C}$ for $30 \mathrm{~min}$. Inoculated flasks were incubated at $28^{\circ} \mathrm{C}$ to $34^{\circ} \mathrm{C}$ for 5 days to obtain sufficient solid state fermented sugar beet pulp for further use to supplement to $\mathrm{PH}$ at different rates. Fermented sugar beet pulp as a carrier of fungal inocula was added at levels of 5.0, 10, and $15 \mathrm{~g} / 100 \mathrm{~g}$ air dried PH and mixed well, then incubated under aerobic conditions for 21 days in a fermentation chamber at $30{ }^{\circ} \mathrm{C}$ and $75 \pm 5 \%$ relative humidity. Three-kilogram $\mathrm{PH}$ was inoculated for each level of fermented sugar beet pulp to in sacco and in vitro gas production studies, while $100 \mathrm{~kg}$ was inoculated at $10 \mathrm{~kg} /$ $100 \mathrm{~kg} \mathrm{PH}$ for the digestibility experiments. After incubation, a peanut hull treated with fungus (PHF) was harvested and sun dried to constant weight to terminate mycelia growth. Samples of the fungal treated PH were collected weekly after onset of incubation for chemical analysis. A total count of fungi was completed according to Collins (1995).

\section{Treatment with urea}

Treatment with urea at $5 \mathrm{~kg} / 100 \mathrm{~kg}$ of material was selected in accordance with Wanapat et al. (2009). Urea was weighed and dissolved in a measured quantity of water to achieve a final moisture content $35 \mathrm{~g}$ water $/ 100 \mathrm{~g}$ of $\mathrm{PH}$. The pile of $\mathrm{PH}$ $(100 \mathrm{~kg})$ was divided to three parts and urea-water solution sprinkled on each part equally and then all parts were mixed together. Airtight conditions were achieved by applying a plastic cover after compacting by trampling. After covering the top of the pile by sealing with plastic, soil was placed beside and over the pile to aid in packing. The pile remained closed for 3 weeks. A sample of treated peanut hulls with urea (i.e., PHU) was dried for chemical analysis, in sacco degradability, and in vitro gas production.

\section{Chemical composition}

Samples of treated materials were oven dried at $60^{\circ} \mathrm{C}$ for $24 \mathrm{~h}$ and stored for later chemical analysis. Chemical analyses included DM (\#942.05), N (\#988.05), EE (\#920.39), ash 
(\#942.05), and true protein (\#988.06) according to AOAC (1997). Non-protein N was calculated by subtracting true protein $\mathrm{N}$ from the total $\mathrm{N}$. Neutral detergent fiber (NDF), acid detergent fiber (ADF), and lignin were determined according to Van Soest et al. (1991) with no sodium sulfite or heat-stable amylase included in the neutral detergent analysis. The NDF and ADF are expressed inclusive of residual ash. Cellulose was calculated as the difference between ADF and lignin.

In sacco and in vitro evaluation

Three individual samples of each of the PH, FPH, and UPH were randomly collected from each test diet to obtain representative samples. Each sample of test diet was used for the in sacco and in vito studies.

\section{In sacco degradation}

Two ruminally fistulated Egyptian water buffalo bulls (Baladi from Lower Egypt) were used to determine in sacco degradation characteristics of DM, OM, and CP. Bulls were fed berseem hay as the basal diet. Samples of PH, FPH, and UPH were milled to pass a $2-\mathrm{mm}$ screen into nylon bags $(10 \times 20 \mathrm{~cm}$ with a surface area of about $210 \mathrm{~cm}^{2}$ with pores of $53 \pm 15 \mu \mathrm{m}$ size used for incubation) in triplicate ( $8 \mathrm{~g}$ dry samples/bag) and anchored with a suitable length of braided fishing line. Degradability was measured at $6,12,24,48,72$, and $96 \mathrm{~h}$.

\section{In vitro gas production}

Rumen fluid was obtained through the rumen fistula before the morning feeding. Bulls were fed the same diets as in the in sacco evaluation. Incubation was in triplicate according to Menke and Steingass (1988) in $120 \mathrm{ml}$ calibrated syringes in three batches at $39^{\circ} \mathrm{C}$. Gas production was measured at 2, 4, $6,8,12,24,36,48$, and $72 \mathrm{~h}$ in triplicate. The average volume of gas produced from the blank was deducted from the volume of gas produced per sample.

Feed intake, digestibility, and rumen fermentation

Four sets of digestion and $\mathrm{N}$ balance evaluations were completed using three native breed Ossimi rams $(64.1 \pm 0.36 \mathrm{~kg}$ body weight) per treatment. Rams were housed individually in metabolism crates which allowed separation of urine and feces, and allowed 15 days to adapt to the diets before a 7-day collection period. An aliquot $(10 \mathrm{~g} / 100 \mathrm{~g})$ of total fecal output was collected each day for digestibility determination and dried at $80{ }^{\circ} \mathrm{C}$ to constant weight before analysis. Urine was collected into buckets containing $100 \mathrm{ml}$ of $100 \mathrm{ml} / 1(\mathrm{v} / \mathrm{v})$ sulfuric acid to reduce $\mathrm{pH}$ below 3.0 and prevent bacterial destruction in urine samples. The volume of urine at each sampling was determined, and a sub-sample $(10 \mathrm{ml} / 100 \mathrm{ml})$ of total urine was collected from each sheep and frozen until analyzed for total $\mathrm{N}$.

During the digestion study, rams were fed at 06:30 and 18:30 hours. As some rams showed considerable diet selectivity the refused feed was collected and chemically analyzed. At the end of the digestibility phase, rumen fluid samples were collected by stomach tube $4 \mathrm{~h}$ post feeding on 2 consecutive days. Rumen samples were analyzed using a $\mathrm{pH}$ meter immediately after sampling and filtration. The concentration of ammonia-N was measured according to Conway (1978). Total short chain fatty acids were determined according to (Eadie et al., 1967), and molar proportions of individual acids were determined by gas chromatography to evaluate rumen fermentation according to the description of Erwin et al. (1961). In addition, samples of rumen liquor were collected for protozoa and bacterial counts.

To count protozoa, preparation of rumen samples followed Dehority (1984) wherein a $0.2 \mathrm{~mm}$ deep chamber under $\times 100$ magnifications was used. Total bacterial populations were counted in a Neubauer chamber under $\times 1,200$ magnification after preparation of rumen samples according to Warner (1964).

\section{Calculations and statistical analysis}

The exponential model $\left\{y=a+b \times\left(1-e^{-c(t-L)}\right)\right\}$ was used to describe the extent and rate of degradability (Ørskov and McDonald, 1979) of DM, OM, and CP. The fraction $y$ being the percentage which disappears in time $t ; a$, the soluble fraction or easily degradable; $b$, the fraction potentially degradable and $c$ the fractional rate of fraction $b$. The factors $a$, $b$, and $c$ in this model are obtained by non-linear decline using the PROC (NLIN) of SAS (2004).

Gas production was assumed to be an indication of substrate fermentation. The kinetic properties of the gas production data were determined using the exponential model for fitting curve $\left\{A=b \times\left(1-e^{-c(t-L)}\right)\right\}$ to mathematically express gas production with time and describe its extent and rate of production (France et al. 2000). $A$ is the volume of gas production at time $t ; b$ the asymptotic gas production ( $\mathrm{ml} / \mathrm{g} \mathrm{DM}) ; c$ is the rate of gas production $(/ \mathrm{h})$ from the slowly fermentable feed fraction $b$, and $L$ is the discrete lag time prior to gas production.

Data of in sacco degradability, in vitro gas production, feed intake, digestibility, rumen fermentation, and $\mathrm{N}$ utilization were analyzed as a randomized block design using the MIXED procedure of SAS (2004). In sacco and in vitro data of each of the three runs within sample were averaged and used as the mean value within treatment, and mean values of each sample within treatment (i.e., PH, PHF, and PHU) were used as the experimental unit. Each ram within each treatment for the in vivo data of feed intake, digestibility, rumen fermentation 
and $\mathrm{N}$ utilization was used as the experimental unit. The full statistical model was:

$\mathrm{Y}_{k l}=\mu+\mathrm{T}_{\mathrm{k}}+\mathrm{E}_{k l}$

where: $\mathrm{Y}_{\mathrm{k} 1}$ expressed every observation of the kth $\mathrm{PH}$ individual samples when treated with the ith treatment, $T_{(1-3)}$ expressed the treatments and $\mathrm{E}$ is the experimental error. Tukey's test was used for the multiple comparisons among mean values for the treatments.

\section{Results}

Content of DM in PH treated with fungus decreased with increased levels of fermented sugar beet pulp inoculums, while $\mathrm{CP}, \mathrm{EE}$, and ash increased. Plant cell wall constituents decreased with increased fermented sugar beet pulp level. The same trend occurred with urea treatment (Table 1).

True protein $\mathrm{N}$ content of $\mathrm{PH}$ increased with fungal treatment level of fermented sugar beet pulp. Total $\mathrm{N}$ of $\mathrm{PH}$ increased with urea treatment to a level comparable to the fungal treatment, whereas true protein $\mathrm{N}$ was decreased in non protein $\mathrm{N}$ (Table 2).

Degradability of DM, OM, and CP with urea treatment were higher than with fungal treatment, which increased $(P<0.05)$ the in vitro DM digestibility of PH from 25 to $40 \mathrm{~g} / 100 \mathrm{~g}$, whereas DM, OM, and $\mathrm{CP}$ were increased $(P<0.05)$ with fungal treatment (Table 3).

Table 1 Chemical composition and cell wall constituents (g/100 g DM) of peanut hull $(\mathrm{PH})$ inoculums with different levels of fungal inoculated with fermented sugar beet pulp or treated with urea

\begin{tabular}{|c|c|c|c|c|c|}
\hline & \multirow[t]{3}{*}{ Untreated PH } & \multicolumn{4}{|c|}{ Treated peanut hulls $(\mathrm{PH})$} \\
\hline & & \multicolumn{3}{|c|}{$\begin{array}{l}\text { Inoculums' ratio with } \\
\text { fermented sugar beet } \\
\text { pulp }(\mathrm{g} / 100 \mathrm{~g} \mathrm{PH})\end{array}$} & \multirow[t]{2}{*}{ Urea } \\
\hline & & 5.0 & 10.0 & 15.0 & \\
\hline \multicolumn{6}{|l|}{ Chemical composition } \\
\hline Dry matter & 92.10 & 65.34 & 65.21 & 65.31 & 65.37 \\
\hline Organic matter & 94.03 & 88.50 & 87.54 & 86.53 & 89.52 \\
\hline Crude protein & 6.67 & 17.42 & 17.69 & 19.41 & 15.57 \\
\hline Ether extract & 0.73 & 1.60 & 1.72 & 2.24 & 1.51 \\
\hline \multicolumn{6}{|l|}{ Cell wall constituents } \\
\hline Neutral detergent fiber & 75.86 & 62.81 & 60.87 & 55.64 & 59.41 \\
\hline Acid detergent fiber & 45.71 & 38.52 & 37.00 & 35.46 & 37.30 \\
\hline Non-fiber carbohydrate & 10.77 & 6.67 & 7.26 & 9.24 & 13.03 \\
\hline Lignin & 8.53 & 7.41 & 7.39 & 7.04 & 7.22 \\
\hline Cellulose & 37.18 & 31.11 & 29.61 & 28.42 & 30.08 \\
\hline Hemicellulose & 30.15 & 24.29 & 23.87 & 20.18 & 22.11 \\
\hline
\end{tabular}

Table 2 Nitrogen fractions (g/100 g DM) of peanut hull (PH) inoculums with different levels of fungal inoculated with fermented sugar beet pulp or treated with urea at 4 weeks of incubation period

\begin{tabular}{|c|c|c|c|c|c|c|}
\hline & \multirow[t]{3}{*}{ Untreated PH } & \multicolumn{4}{|c|}{ Treated peanut hulls } & \multirow[t]{3}{*}{$\pm \mathrm{SE}$} \\
\hline & & \multicolumn{3}{|c|}{$\begin{array}{l}\text { Inoculums' ratio } \\
\text { with fermented } \\
\text { sugar beet pulp } \\
\text { (g/100 g PH) }\end{array}$} & \multirow[t]{2}{*}{ Urea } & \\
\hline & & 5.0 & 10.0 & 15.0 & & \\
\hline Total protein & 1.07 & 2.23 & 2.29 & 2.49 & 2.17 & 0.170 \\
\hline True protein $\mathrm{N}$ & $1.03^{\mathrm{b}}$ & $1.97^{\mathrm{a}}$ & $2.04^{\mathrm{a}}$ & $2.20^{\mathrm{a}}$ & $0.53^{\mathrm{b}}$ & 0.150 \\
\hline Non protein $\mathrm{N}$ & $0.04^{\mathrm{b}}$ & $0.26^{\mathrm{b}}$ & $0.26^{\mathrm{b}}$ & $0.29^{\mathrm{b}}$ & $1.65^{\mathrm{a}}$ & 0.041 \\
\hline $\begin{array}{l}\text { True protein N/total } \\
\text { protein }\end{array}$ & $0.96^{\mathrm{a}}$ & $0.87^{\mathrm{a}}$ & $0.88^{\mathrm{a}}$ & $0.87^{\mathrm{a}}$ & $0.24^{\mathrm{b}}$ & 0.016 \\
\hline $\begin{array}{l}\text { Non protein } \mathrm{N} / \text { total } \\
\text { protein }\end{array}$ & $0.04^{\mathrm{b}}$ & $0.13^{\mathrm{b}}$ & $0.12^{\mathrm{b}}$ & $0.13^{\mathrm{b}}$ & $0.76^{\mathrm{a}}$ & 0.016 \\
\hline
\end{tabular}

Values within a column with different superscripts differ $(P<0.05)$

Gas production of the insoluble fraction $(b)$ increased $(P<0.05)$ with fungal treatment versus untreated $\mathrm{PH}$ or PHU. Gas production increased $(P<0.05)$ in PHF and followed by PHU and decreased $(P<0.05)$ in PH (Table 4$)$.

Fungal treatment increased $(P<0.05)$ feed intake of PHF versus $\mathrm{PH}$ and $\mathrm{PHU}$ by $18 \%$ and $25 \%$, respectively. Digestibility of OM, CP, NDF, and non-fiber carbohydrate for PHF increased $(P<0.05)$ versus untreated or urea treated PH. All nutrient digestibilities were higher with PHF and PHU versus $\mathrm{PH}$, whereas digestibility of $\mathrm{DM}, \mathrm{EE}$, and $\mathrm{ADF}$ did not differ between PHF and PHU. The intake, losses and balance of $\mathrm{N}$ increased $(P<0.01)$ with PHF versus $\mathrm{PH}$ feeding (Table 5).

Feeding PHF increased $(P<0.01)$ levels of $\mathrm{NH}_{3}-\mathrm{N}$, acetic acid, butyric acid and the acetic to propionic acid ratio. Bacterial and protozoal counts increased $(P<0.05)$ with feeding PHF or PHU versus PH (Table 6).

\section{Discussion}

Increased CP content of forages following urea treatment have been widely reported (Sundstol et al. 1978; Kiangi 1981), and it is well known that urea treatment is a practical method to increase the $\mathrm{N}$ content of low quality feeds. The reduction in fiber content after treatment with urea or fungal was due to the reduction in hemicellulose. During ammonia treatment, lignin may have dissociated from the lignocellulosic complex but was still detected as lignin. Others have suggested reasons for the improvements after urea treatment of crop residues, which include collapse of vascular bundle sheath cells in treated crop residues, rupture of inner cuticular surfaces and separation from adjacent ground parenchyma, alteration in the friability of the rigid layer covering the inner 
Table 3 In sacco rumen degradability of dry matter (DM), organic matter (OM) and crude protein $(\mathrm{CP})$ of treated and untreated peanut hulls $(\mathrm{g} / 100 \mathrm{~g}$ DM)

\begin{tabular}{|c|c|c|c|c|c|c|c|c|c|}
\hline \multirow[t]{2}{*}{ Nutrient } & \multirow[t]{2}{*}{ Treatment $^{1}$} & \multicolumn{8}{|c|}{ Parameters ${ }^{2}$} \\
\hline & & W & $a$ & $b$ & $c$ & PD & B & ED & UND \\
\hline \multirow[t]{4}{*}{ DM } & $\mathrm{PH}$ & $7.1^{\mathrm{c}}$ & $3.67^{\mathrm{c}}$ & 56.2 & 0.019 & $59.8^{\mathrm{b}}$ & $52.8^{\mathrm{a}}$ & $19.1^{\mathrm{b}}$ & $40.2^{\mathrm{a}}$ \\
\hline & PHF & $10.3^{\mathrm{b}}$ & $5.10^{\mathrm{b}}$ & 61.9 & 0.027 & $67.0^{\mathrm{ab}}$ & $56.7^{\mathrm{ab}}$ & $26.8^{\mathrm{ab}}$ & $33.1^{\mathrm{ab}}$ \\
\hline & PHU & $15.3^{\mathrm{a}}$ & $15.52^{\mathrm{a}}$ & 63.0 & 0.014 & $78.5^{\mathrm{a}}$ & $63.2^{\mathrm{a}}$ & $29.3^{\mathrm{a}}$ & $21.5^{\mathrm{b}}$ \\
\hline & $\pm \mathrm{SE}$ & 1.22 & 0.79 & 4.40 & 0.017 & 3.69 & 4.40 & 3.69 & 3.69 \\
\hline \multirow[t]{4}{*}{$\mathrm{OM}$} & $\mathrm{PH}$ & $7.8^{\mathrm{c}}$ & $4.1^{\mathrm{b}}$ & 50.9 & $0.026^{\mathrm{ab}}$ & $55.0^{\mathrm{b}}$ & $47.2^{\mathrm{b}}$ & $21.5^{\mathrm{b}}$ & $45.0^{\mathrm{a}}$ \\
\hline & PHF & $11.3^{\mathrm{b}}$ & $4.4^{\mathrm{b}}$ & 72.6 & $0.028^{\mathrm{a}}$ & $77.0^{\mathrm{a}}$ & $65.7^{\mathrm{a}}$ & $30.5^{\mathrm{a}}$ & $23.0^{\mathrm{b}}$ \\
\hline & PHU & $16.9^{\mathrm{a}}$ & $15.9^{\mathrm{a}}$ & 57.3 & $0.017^{\mathrm{b}}$ & $73.1^{\mathrm{a}}$ & $56.3^{\mathrm{ab}}$ & $30.4^{\mathrm{a}}$ & $26.9^{\mathrm{b}}$ \\
\hline & $\pm \mathrm{SE}$ & 1.34 & 1.86 & 6.79 & 0.0031 & 6.30 & 6.04 & 6.30 & 6.30 \\
\hline \multirow[t]{4}{*}{$\mathrm{CP}$} & PH & $4.0^{\mathrm{b}}$ & $4.3^{\mathrm{c}}$ & 49.0 & $0.015^{\mathrm{ab}}$ & $53.0^{\mathrm{b}}$ & 49.0 & 15.0 & $47.0^{\mathrm{a}}$ \\
\hline & PHF & $5.6^{\mathrm{b}}$ & $6.6^{\mathrm{b}}$ & 46.0 & $0.026^{\mathrm{a}}$ & $52.0^{\mathrm{b}}$ & 47.0 & 22.0 & $48.0^{\mathrm{a}}$ \\
\hline & PHU & $19.5^{\mathrm{a}}$ & $20.7^{\mathrm{a}}$ & 55.0 & $0.007^{\mathrm{b}}$ & $75.0^{\mathrm{a}}$ & 56.0 & 27.0 & $25.0^{\mathrm{b}}$ \\
\hline & $\pm \mathrm{SE}$ & 1.24 & 1.60 & 12.30 & 0.01 & 11.9 & 12.4 & 10.7 & 11.7 \\
\hline
\end{tabular}

Values within a column and within DM, OM, or CP with different superscripts differ $(P<0.05)$

${ }^{1} \mathrm{PH}=$ untreated peanut hulls; $\mathrm{PHF}=$ treated peanut hulls with fungi; $\mathrm{PHU}=$ treated peanut hulls with urea

${ }^{2} \mathrm{~W}$ is the washing loss (g/100 g DM); $a$, the soluble fraction or easily degradable; $b$, the fraction potentially degradable; $c$, the fractional rate of fraction $b$; PD is the potential degradability $(\mathrm{g} / 100 \mathrm{~g} \mathrm{DM}) ; \mathrm{B}(\mathrm{g} / 100 \mathrm{~g} \mathrm{DM})=(\mathrm{a}+\mathrm{b})-\mathrm{W}$; ED is the effective degradability $(\mathrm{g} / 100 \mathrm{~g}$ DM; $\mathrm{UND}$ is the undegradable fraction (UND, g/100 g DM) $=100-(a+b)$

surface of cell walls and the ability of $\mathrm{NH}_{3}$ to form an ammonia-cellulose complex and to decrease cellulose crystallinity (Goto et al. 1993). Goto et al. (1993) also argued that any reduction in the crystallinity of cellulose forming microfibrils of the cell walls could contribute to increased fragility of the wall which consequently increases susceptibility to attack by cellulolytic microbes. These factors may explain the increase in in vitro digestibility with treated residues. It is also known that $\mathrm{NH}_{3}$ can dissolve hemicellulose and cleave ester bonds of uronic acids with loss of acetyl groups thereby releasing acetyl and phenolic acids, an effect which may

Table 4 Effects of fungal and urea treatments of peanut hulls on in vitro gas production kinetics

\begin{tabular}{llll}
\hline Treatment $^{1}$ & \multicolumn{2}{l}{ Gas kinetics $^{2}$} & \\
\cline { 2 - 4 } & $b(\mathrm{ml} / 100 \mathrm{~g} \mathrm{DM})$ & $c(/ \mathrm{h})$ & $L(\mathrm{~h})$ \\
\hline PH & $28.9^{\mathrm{b}}$ & $0.028^{\mathrm{b}}$ & 4.84 \\
PHF & $61.2^{\mathrm{a}}$ & $0.062^{\mathrm{b}}$ & 3.67 \\
PHU & $46.0^{\mathrm{ab}}$ & $0.128^{\mathrm{a}}$ & 1.32 \\
\pm SE & 5.12 & 0.0131 & 0.105 \\
\hline
\end{tabular}

Values within a column with different superscripts differ $(P<0.05)$

${ }^{1} \mathrm{PH}=$ untreated peanut hulls; $\mathrm{PHF}=$ treated peanut hulls with fungi; $\mathrm{PHU}=$ treated peanut hulls with urea

${ }^{2} b$ is the asymptotic gas production $(\mathrm{ml} / \mathrm{g} \mathrm{DM}) ; c$ is the rate of gas production $(/ \mathrm{h}) ; L$ is the initial delay before gas production begins (h) explain the decreases in NDF and ADF maize residues (Oji et al.2007). As rumen fill can be a limitation to productivity of ruminants eating straw, these reductions in NDF caused by ammonia treatment are encouraging because they imply that the degradability and intake of straw may be improved.

The increased of CP content in the substrates treated with fungus could also be due to capture of $\mathrm{N}$ by aerobic fermentation (Akinfemi et al. 2010). Such an increase in CP has been reported to be associated with increased fungal biomass (Mehrez et al. 2008). The content of true protein $\mathrm{N}$ increased as a result of fungal growth, a result consistent with Rahman and Mahmood (2008), indicating that the decrease of OM indices and increased of microbial protein in our study were relatively good predictors of microbial protein mass.

The increased in $\mathrm{CP}$ of the treated straw is consistent with Abdel-Azim et al. (2011) who stated that the extracellular enzymes secreted by the fungus contain amorphous homo and hetero polysaccharides which often associate with protein (fungal protein). The increment in $\mathrm{CP}$ was comparable to the $\mathrm{CP}$ contents of those reported in most tropical cereal crops. This is also consistent with the findings of Akinfemi et al. (2010) who observed an increased in the CP content of maize husk when treated with white-rot fungi. In contrast, the crude fibre level decreased in all our fungal treated substrates. Abo-Donia et al. (2005) attributed such decreases in fiber to the ability of fungi to secrete hydrolyzing and oxidizing enzymes, which could convert the recalcitrant compounds in the waste into utilizable compounds (Abdel-Azim et al. 2011). 
Table 5 Feed intake, nutrient digestibility, nutritive values and $\mathrm{N}$ balance in Ossimi sheep fed peanut hulls treated with fungi and urea
Values within a row with different superscripts differ $(P<0.05)$

$S E M$ slandered error of the mean

${ }^{1} \mathrm{PH}=$ untreated peanut hulls; $\mathrm{PHF}=$ treated peanut hulls

with fungi; $\mathrm{PHU}=$ treated peanut hulls with urea

\begin{tabular}{|c|c|c|c|c|c|}
\hline & \multicolumn{3}{|c|}{ Treatments $^{1}$} & \multirow[t]{2}{*}{ SEM } & \multirow[t]{2}{*}{$P$ value } \\
\hline & $\mathrm{PH}$ & PHF & PHU & & \\
\hline Offered feed $(\mathrm{kg} / \mathrm{h} / \mathrm{d})$ & 1.50 & 1.50 & 1.50 & - & - \\
\hline Feed intake $(\mathrm{kg})$ & $1.00^{\mathrm{ab}}$ & $1.22^{\mathrm{a}}$ & $0.92^{\mathrm{b}}$ & 0.071 & 0.041 \\
\hline Refused diet $(\mathrm{kg} / \mathrm{h} / \mathrm{d})$ & 0.50 & 0.28 & 0.58 & 0.075 & 0.180 \\
\hline Refused/Intake & 0.50 & 0.24 & 0.62 & 0.117 & 0.241 \\
\hline Relative palatability (g/100 g feed consumed ) & 0.48 & 0.76 & 0.36 & 0.115 & 0.088 \\
\hline \multicolumn{6}{|l|}{ Nutrient digestibility $(\mathrm{g} / 100 \mathrm{~g})$ : } \\
\hline Dry matter & $46.07^{\mathrm{b}}$ & $51.49^{\mathrm{a}}$ & $49.64^{\mathrm{a}}$ & 0.820 & 0.009 \\
\hline Organic mater & $49.24^{\mathrm{c}}$ & $55.13^{\mathrm{a}}$ & $51.47^{\mathrm{b}}$ & 0.651 & 0.002 \\
\hline Crude protein & $34.6^{\mathrm{c}}$ & $53.5^{\mathrm{a}}$ & $42.9^{\mathrm{b}}$ & 1.38 & $<0.001$ \\
\hline Ether extract & $57.5^{\mathrm{b}}$ & $63.7^{\mathrm{a}}$ & $61.6^{\mathrm{ab}}$ & 1.43 & 0.053 \\
\hline Neutral detergent fiber & $49.42^{\mathrm{b}}$ & $52.87^{\mathrm{a}}$ & $50.06^{\mathrm{b}}$ & 0.553 & 0.009 \\
\hline Acid detergent fiber & $40.3^{\mathrm{b}}$ & $46.5^{\mathrm{a}}$ & $44.4^{\mathrm{a}}$ & 1.08 & 0.019 \\
\hline Non-fiber carbohydrate & $46.3^{\mathrm{b}}$ & $69.8^{\mathrm{a}}$ & $53.2^{\mathrm{b}}$ & 2.56 & 0.002 \\
\hline \multicolumn{6}{|l|}{ Nitrogen balance $(\mathrm{g} / \mathrm{h} / \mathrm{d})$ : } \\
\hline Intake & $10.4^{\mathrm{c}}$ & $37.7^{\mathrm{a}}$ & $16.1^{\mathrm{b}}$ & 1.44 & $<0.001$ \\
\hline Loss in feces and urine & $11.2^{\mathrm{c}}$ & $37.1^{\mathrm{a}}$ & $16.2^{\mathrm{b}}$ & 1.32 & $<0.001$ \\
\hline Retention & $-0.80^{\mathrm{b}}$ & $0.62^{\mathrm{a}}$ & $-0.12^{\mathrm{ab}}$ & 0.260 & 0.023 \\
\hline
\end{tabular}

Similar decreases were obtained in the values of NDF, lignin, and ADF, which could be indicative of degradation of the cell wall components of the substrates produced by the extracellular enzymes of the fungi (Akinfemi et al., 2010).

Others concluded that lignification of structural polysaccharides inhibited ruminal microbial digestion of polysaccharides

Table 6 Patterns of rumen fermentation after $4 \mathrm{~h}$ of feeding in Ossimi sheep fed peanut hulls treated with fungi and urea

\begin{tabular}{|c|c|c|c|c|c|}
\hline & \multicolumn{3}{|c|}{ Treatments $^{1}$} & \multirow[t]{2}{*}{ SEM } & \multirow[t]{2}{*}{$P$ value } \\
\hline & $\mathrm{PH}$ & PHF & PHU & & \\
\hline $\mathrm{pH}$ & 5.81 & 5.93 & 5.95 & 0.239 & 0.892 \\
\hline $\mathrm{NH}_{3}-\mathrm{N}(\mathrm{mg} / \mathrm{dl})$ & $13.63^{\mathrm{b}}$ & $17.51^{\mathrm{a}}$ & $18.38^{\mathrm{a}}$ & 0.701 & 0.007 \\
\hline \multicolumn{6}{|l|}{ Short chain fatty acids } \\
\hline Total, meq/dl & $17.91^{\mathrm{b}}$ & $20.08^{\mathrm{a}}$ & $18.84^{\mathrm{ab}}$ & 0.562 & 0.088 \\
\hline \multicolumn{6}{|c|}{ Individuals acids, molar proportions } \\
\hline Acetic acid & $55.25^{\mathrm{b}}$ & $57.52^{\mathrm{a}}$ & $56.95^{\mathrm{a}}$ & 0.481 & 0.035 \\
\hline Propionic acid & $34.86^{\mathrm{a}}$ & $30.25^{\mathrm{b}}$ & $30.56^{\mathrm{b}}$ & 0.341 & 0.002 \\
\hline Butyric acid & $13.05^{\mathrm{b}}$ & $14.60^{\mathrm{a}}$ & $14.46^{\mathrm{a}}$ & 0.131 & $<0.001$ \\
\hline Acetic/Propionic ratio & $1.58^{\mathrm{b}}$ & $1.90^{\mathrm{a}}$ & $1.86^{\mathrm{a}}$ & 0.010 & $<0.001$ \\
\hline Bacteria count, $\left(\mathrm{x} 10^{9} / \mathrm{ml}\right)$ & $2.71^{\mathrm{b}}$ & $2.82^{\mathrm{a}}$ & $2.79^{\mathrm{a}}$ & 0.022 & 0.033 \\
\hline Protozoa count $\left(\times 10^{5} / \mathrm{ml}\right)$ & $8.49^{\mathrm{b}}$ & $8.83^{\mathrm{a}}$ & $8.75^{\mathrm{a}}$ & 0.071 & 0.036 \\
\hline
\end{tabular}

Values within a row with different superscripts differ $(P<0.05)$

${ }^{1} \mathrm{PH}=$ untreated peanut hulls; $\mathrm{PHF}=$ treated peanut hulls with fungi; $\mathrm{PHU}=$ treated peanut hulls with urea by forming a 3-D matrix and that the presence of highly lignified tissues formed a physical barrier preventing the accessibility of the otherwise highly digestible tissues to the action of hydrolytic enzyme of the rumen microorganisms (Abo-Donia et al. 2005), while Akinfemi et al. (2010) showed that increased digestibility was associated with degradation of structural carbohydrates.

Decreased NDF and ADF with fungal treatment could be indicative of degradation of cell wall components of the substrates produced by the extracellular enzymes of the fungi. Akinfemi et al. (2010) postulated that this decrease in fibre content may be related to utilization of carbohydrates by the fungus as an energy source for mycelia growth.

Improved degradability of $\mathrm{DM}, \mathrm{OM}$, and $\mathrm{CP}$ with urea treatment may be due to ammonia, released by urea hydrolyses and trapped in the bag, which caused increased $\mathrm{N}$ loss as continuous loss of ammonia. The increased DM and OM digestion in the fungal treated substrates, which may be indicative of degradation of cell wall components by fermentation by bacteria and protozoa (Barton et al. 1974; Abdel-Azim et al. 2011). Dckkcr and Richards (1973) reported a correlation between the lignin content of peanut hulls and its DM and OM degradability.

Fungal and urea treatments increased gas production, suggesting that Trichoderma and urea treatments loosened the lignucelluletic bonds and solublized some of the hemicellulose and the soluble fraction $(a)$, thereby making it more easily attachable by ruminal microorganisms leading to a higher production of short chain fatty acids, gases (mainly $\mathrm{CO}_{2}$ and $\mathrm{CH}_{4}$ ) or microbial cells (Abdel-Azim et al. 2011). Kinetics of gas 
production depend on the relative proportions of soluble and insoluble particles of feed (Makkar et al. 1999), but gas production can be regarded as an indicator to carbohydrate degradation where gas production is basically the result of fermentation of carbohydrates to acetate, propionate and butyrate (Wolin 1960). Our gas production values are within the range of reported values (Singh et al. 2011).

Decreased digestibility of NDF for PH might be due to the cellulose in untreated peanut hulls being less digestible than when treated, which could cause a degree of polymerization (Jain and Wilkins 1987), crystallinity (Pandey et al. 2000), branching (Fan et al. 1982) and sites, and number of cross linkage with other plant polymers, or combinations. Our results are consistent with El-Menniawy (2008) who reported that biological treatment of fibrous feeds resulted in improved DM, EE, and ADF digestibility. Shakweer (2003) reported that the increase in apparent digestibility of $\mathrm{CP}$ may be attributed to better digestibility of most nutrients due to this treatment, and/or an increase in rumen fermentation capacity.

Increased $\mathrm{N}$ balance for PHF versus $\mathrm{PHU}$ and $\mathrm{PH}$ might be related to increased $\mathrm{N}$ intake and $\mathrm{N}$ digestibility. $\mathrm{N}$ intake and balance values are consistent with Ibrahim (2002) who reported that biological treatments of forages raised $\mathrm{N}$ balance values with various animals. This may be due to a lack of $\mathrm{NH}_{3}-\mathrm{N}$ release in the rumen with fungi treatment, in addition to carbohydrates that broke away to provide a source of energy for microbial growth, which increases microbial mass resulting in a higher $\mathrm{N}$ balance.

The rate of carbohydrate supply influences the amount of ruminal $\mathrm{NH}_{3}-\mathrm{N}$ assimilated into microbial protein. At the same time, increased ruminal $\mathrm{NH}_{3}-\mathrm{N}$ presumably relates to production of microbial protein in the rumen which is affected by the amount and source of consumed N. A major part of ruminal $\mathrm{NH}_{3}-\mathrm{N}$ is created by bacteria and protozoa (El-Sayed et al. 2002). The concentration of short chain fatty acids in rumen fluid is influenced by the physical state of forage consumed, level of intake (Mehrez et al. 2008), and the optimum $\mathrm{pH}$ value for cellulolytic bacterial growth (Martens 1977).

\section{Conclusions}

A peanut hull has very low nutritive quality as a livestock feed. Treated PH with urea or T. viride caused changes in chemical compositions and in vitro digestibility. Fungal treatment with T. viride is more technically cumbersome to handle and may expose the handler to health hazards while urea does not have these problems and moreover, it is less expensive. Even though fungal treatments were efficient in improving the nutritive value of low quality forages, our results suggest use of urea for upgrading the $\mathrm{N}$ of poor quality crop residues.

\section{References}

Abdel-Azim, S.N., Ahmed, M.A., Abo-Donia, F. and Soliman, H., 2011. Evaluation of fungal treatment of some agricultural residues. Egyptian Journal of Sheep and Goat Sciences, 6, 1-13.

Abo-Donia, F.M, Sobhy, H., El-Gamal, K.M. and Mikhail, W.Z.A., 2005. Evaluation of applying the solid-state fermentation technique to upgrade chemical and sugar cane bagasse. Egyptian Journal of Nutrition and Feeds, 8, 603-617.

Akinfemi, A. Adu, O.A. and Doherty, F. 2010. Conversion of sorghum stover into animal feed with white-rot-fungi. Pleurotus oestreatus and Pleurotus pulmonarius. African Journal of Biotechnology, 9, $1706-1712$.

AOAC, Association of Official Analytical Chemists, 1997. Official Methods of Analysis, 16th ed. AOAC, Arlington, VA, USA.

Barton, F.E., Amos, H.E., Albrecht, W.J. and Burdick, D., 1974. Treating peanut hulls to improve digestibility for ruminants. Journal of Animal Science, 38, 860-864.

Collins, M. 1995. Hay preservation effects on yield and quality. In: D. M. Kral, et al. (eds.) Postharvest physiology and preservation of forages. CSSA Specification Publication, 22, 67-89.

Conway, E.J., 1978. Microdiffusion analysis and volumetric error. 4th Ed. The McMillan Co., New York, NY, USA.

Dckkcr, R.F.H., Richards, G.N., 1973. Effect of delignification on the in vitro rumen digestion of polysaccharides of Bagasse. Journal of the Science of Food and Agriculture, 24, 375-379.

Dehority, B.A., 1984. Evaluation of subsampling and fixation procedures used for counting rumen protozoa. Applied and Environmental Microbiology, 48, 182-185.

Eadie, J.M., Hobson, P.N., Mann, S.O., 1967. A note on some comparisons between the rumen content of barley fed steers and that of young calves also fed on high concentrate rations. Animal production, 9, 247-250.

Egyptian ministry of Agriculture and Land Reclamation, 2006. Study of the indicators agricultural statistics. Vol. 2: Summer and Nile Crops 2005. Central administration for agricultural economy.

El-Menniawy, A.Y.M., 2008. Studies on biological treatments in animal nutrion. Ph.D. Thesis. Fac. Agriculture, Al-Azhar University, Nasser city, Egypt.

El-Sayed, H.M., El-Ashry, M.A., Metwally, H.M., Fadel, M. and Khorshed, M.M., 2002. Effect of chemical and biological treatments of some crop-residues on their nutritive value: 3-Digestion coefficient, rumen and blood serum parameters of Goats. Egyptian Journal of Nutrition and Feeds, 1, 55-66.

Erwin, E.S., Marco, G.T. and Emery, E.M., 1961. Volatile fatty acid analysis of blood and rumen fluid by gas chromatography. Journal of Dairy Science, 44, 1768-1771.

Fan, L.T., Lee, Y.H. and Gharpuray, M.M., 1982. The nature of lignocellulosics and their pre-treatment for enzymic hydrolysis. Advanced Biochemical Engineering, 23, 157-187.

France, J., Dijkstra, J., Dhanoa, M.S., Lopez, S. and Bannink, A., 2000. Estimating the extent of degradation of ruminant feeds from a description of their gas production profiles observed in vitro: derivation of models and other mathematical considerations. British Journal of Nutrition, 83, 143-150.

Frank Dean, J., 2002. Effects of differences in dietary protein and varying the interval from collection of bovine embryos to freezing on embryo quality and viability. MSc. Thesis. Virginia Polytechnic Institute, Virginia City, USA.

Goto, M., Yokoe, Y., Takabe, K. Nisikawa, S. and Morita, O., 1993. Effects of gaseous ammonia on chemical and structural features of cell walls in spring barley straw. Animal Feed Science Technology, 40, 207-221. 
Ibrahim, M.Y., 2002. Nutritional studies on biological treatment of agriculture by-products on ruminants. M. Sci. Thesis, Fac. of Agric., Zagazig University, Zagazig city, Egypt.

Jain, P. and Wilkins, E.S., 1987. Cellulase immobilized on modified nylon for saccharification of cellulose. Biotechnology and Bioengineering, 30, 1057-1062.

Khaled, M.E., 2009. Improving roughages feeding values by using of fungal treatment in North Africa. MSC. Thesis. Institute of African Research and Studies, Cairo University, Cairo, Egypt.

Kiangi, E.M.I., 1981. Ammonia treatment of low quality roughages to improve their nutritive value. In: Kategile J A, Said A N and Sundstol F (eds), Utilization of low quality roughages in Africa. Proc. of a workshop held at Arusha, Tanzania, 18-22 January. AUN Agricultural Development Report 1. AUN (Agricultural University of Norway), Aas, Norway. pp. 49-54.

Makkar, H.P.S., Aregheore, E.M. and Becker, K., 1999. Effect of saponins on the recovery of ammonia during urea-ammunition of wheat straw and fermentation kinetics of the treated straw. Journal of Agricultural Science, Cambridge, 132, 313-321.

Martens, D.R., 1977. Dietary fiber components: Relationship to the rate and extent of ruminal digestion. Federation Proceedings, 36, 187-192.

Mehrez, A.Z., Abo-Donia, F.M., Maklad, E.H. and Abdel-Khabir, A. 2008. Evaluation of sugar beet pulp treated with Trichoderma verdi and Saccharomyces cervicia. Egyptian Journal of Sheep and Goat Sciences, 3(1), 33-50.

Menke, K.H., Steingass, H. 1988. Estimation of the energetic feed value obtained from chemical analyses and gas production using rumen fluid. Animal Research Development, 28, 7-55.

Oji, U.I., Etim, H.E. and Okoye, F.C., 2007. Effects of urea and aqueous ammonia treatment on the composition and nutritive value of maize residues. Small Ruminant Research, 69, 232-236.

Ørskov, E.R. and McDonald, I., 1979. The estimation of protein degradability in the rumen from incubation measurements weighted according to rate of passage. Journal Agricultural Sciences, 92, 499-503.

Pandey, A, Soccol, C.R. and Mitchell, D., 2000. New developments in solid state fermentation, Process Biochemistry 35, 1153-1169.
Rahman, S.R. and Mahmood, S., 2008. Production and partial characterization of extracellular $\infty$-Amylase by Trichoderma viride. Bangladesh Journal of Medical Science, 25, 99-103.

Raimbault, M., 1998. General and microbiological aspects of solid substrate fermentation. Electron Journal of Biotechnology, 1(3), 1-15.

Rane, S., Puniya, A.K. and Singh, K., 2004. Effect of fungi and N-fixing bacteria on the solid state fermentation of rice straw. Indian Journal of Animal Science, 74, 211-215.

Sarnklong, C., Cone, J.W., Pellikaan, W. and Hendriks, W.H., 2010. Utilization of rice straw and different treatments to improve its feed value for ruminants: A review. Asian-Australasian Journal of Animal Sciences, 23, 680-692.

SAS, 2004. SAS User's Guide: Statistics. SAS Institute. Inc. Cary, NC, USA.

Shakweer, I.M.E., 2003. Effect of biological treatments of rice straw and sugar cane bagasse on their digestibility, nutritive value, ruminal activity and some blood parameters in rams. Egyptian Journal of Nutrition and Feeds, 6, 925.

Singh, S., Kushwaha, B.P., Nag, S.K., Mishra, A.K., Bhattacharya, S., Gupta, P.K. and Singh, A., 2011. In vitro methane emission from Indian dry roughages in relation to chemical composition. Current Science, 101, 1-0.

Sundstol F., Coxworth, E., Mowat, D.N., 1978. Improving the nutritive value of straw and other low quality roughages by treatment with ammonia. World Animal Review 26, 13-21.

Thomas J.K., Windham, W.R, Woodward, J.H., Benner, R., 1986. Chemical composition and in vitro digestibility of thermochemically treated peanut hulls. Journal of the Science of Food and Agriculture, 37, 632-636.

Van Soest, P.J., Robertson, J.B. and Lewis, B.A., 1991. Methods for dietary fiber, neutral detergent fiber, and non-starch polysaccharides in relation to animal nutrition. Journal of Dairy Science, 74, 3583-3597.

Wanapat, M., Polyorach, S., Boonnop, K., Mapato, C. and Cherdthong, A., 2009. Effects of treating rice straw with urea or urea and calcium hydroxide upon intake, digestibility, rumen fermentation and milk yield of dairy cows. Livestock Science, 125, 238-24.

Warner, E., 1964. Production of volatile fatty acids in the rumen. Methods of measurements. Nutrition Abstracts and Reviews, 34, 339-352.

Wolin, M.J., 1960. A theoretical rumen fermentation balance. Journal of Dairy Science, 43, 1452-1459. 